\title{
Organizational Justice, Behavioral Ethics, and Corporate Social Responsibility: Finally the Three Shall Merge
}

\author{
Deborah E. Rupp, ${ }^{1}$ Patrick M. Wright,${ }^{2}$ Samuel Aryee,${ }^{3}$ \\ and Yadong Luo ${ }^{4}$ \\ ${ }^{1}$ Purdue University, USA, ${ }^{2}$ University of South Carolina, USA, ${ }^{3}$ King's College London, UK, and \\ ${ }^{4}$ University of Miami, USA
}

\section{INTRODUGTION}

Issues of ethics, justice, and social responsibility are as fundamental to organizational behavior as they are to society at large. As contracts are forged, individuals employed, and power differentials created, opportunities for exploitation, oppression, and victimization emerge. In contrast, as social structures evolve, coordinated opportunities arise for imparting positive social change at the community, environmental, and societal levels. Inherent to all of these phenomena is the application of norms surrounding moral behavior. Norms about what is considered fair and ethical underlie how individuals perceive and evaluate the behaviors and decisions of others; how groups and societies define acceptable behavior; and how individuals, groups, and societies evaluate the decisions and actions of organizations. In addition to defining standards, these norms also drive the reactions (or sanctions) against those who violate them.

In developing the theme for this special issue, we looked across the management domain for literatures touching on the intersection of morality and organizational behavior. This search led us to three rich literatures, which, while at times intersecting, have never been brought together or showcased together in a systematic way.

\section{THREE LITERATURES IN NEED OF FURTHER INTEGRATION}

Justice

Organizational justice deals with how fairly employees feel various stakeholders treat them. Studies on organizational justice analyze perception formation, the 
cognitive and emotional processing of events, attitudinal and behavioral reactions to perceived mistreatment, and the formation of justice climates within workgroups and organizations (Rupp, 2011). We have accumulated a deep knowledge on these issues from the last 50 years of research in this area. We know that justice and fairness matter to employees. Multiple meta-analytic investigations have shown employee justice perceptions to predict a wide array of organizational- and employee-relevant attitudes and behaviors (Colquitt et al., 2013; Rupp, Shao, Jones, \& Liao, 2014). When employees feel they have been treated fairly, they respond with citizenship, heightened performance, and commitment, and show higher levels of well-being. In contrast, when they perceive unfairness in the workplace, they show signs of stress and withdrawal, and display more counterproductive work behaviors.

Research has also provided explanations for employees' reactions to perceived justice or injustice. It seems that perceptions of fairness are important to employees in assessing the fulfillment of a number of universal needs (Cropanzano, Rupp, Mohler, \& Schminke, 2001; Cropanzano, Byrne, Bobocel, \& Rupp, 2001). That is, employees care about fairness out of self-interest (i.e., to maximize their outcomes and fulfill needs for control; Gillespie \& Greenberg, 2005); they care about fairness out of relational concerns (i.e., to solidify trust-based exchange relationships, especially with those with authority over them, fulfilling their need for belongingness; Tyler \& Lind, 1992); and they care about fairness due to what seems to be an evolutionarily based, universally held moral norm of justice (i.e., to fulfill needs for meaningful existence; Cropanzano, Goldman, \& Folger, 2003; Folger, 1998). The last set of findings about moral norms is particularly relevant to our understanding of justice in the workplace in that it suggests that employees not only respond to the fairness of their own treatment, but they can also have reactions to injustice targeted at others, even when these other victims are dissimilar or unconnected interpersonally to the observer-employee (Kahneman, Knetsch, \& Thaler, 1986; Turillo, Folger, Lavelle, Umphress, \& Gee, 2002). Finally, although employees may have the capacity to report on their general, overall sense of workplace fairness (Ambrose \& Schminke, 2009), as well as their general, overall evaluation of particular facets of justice (e.g., distributive, procedural, interpersonal justice; Colquitt, 2001), research suggests that justice perceptions reflect a complex aggregation of events and judgments about individual parties (e.g., supervisors, clients, coworkers) that we are just beginning to understand (Lavelle, Rupp, Manegold, \& Thornton, in press).

This special issue offers a number of insights on how the normative rules influencing what is considered fair treatment within organizations may vary across cultures. Guo and Miller (2015) explore how employees in Chinese vs. Western contexts apply differential norms in assessing what is fair. Whereas research has demonstrated universality regarding expectations of fair treatment across cultures (Leung, 2005; Shao, Rupp, Skarlicki, \& Jones, 2013), this paper is unique in that it explores the relative importance of different justice dimensions across cultures. Although Guo and Miller found many justice dimensions to be common to both 
Chinese and Western contexts, two emic (culture-specific) dimensions also emerged (propriety and respect in the West and the principle of ren in the Chinese context). We also learn from this study that justice may be interpreted with a higher level of subjectivity in the Chinese context.

Liu, Keller, and Hong (2015) further contextualize these ideas through a comparative analysis of the extent to which the practice of hiring individuals with varying levels of qualifications and varying degrees of personal ties (with the employer, its business associates, or government officials) is considered fair and effective in China and the United States. This study not only reveals the complexity with which individuals apply norms, beliefs, and cultural values in assessing the actions of a firm, it also challenges common beliefs surrounding attitudes toward favoritism in Chinese society - with important implications for research on Confucian relationalism.

\section{Behavioral Ethics}

Behavioral ethics considers those interactions between individual behavior and social contexts that involve morality-based social prescriptions and moral norms (Cropanzano \& Stein, 2009; Trevino, Weaver, \& Reynolds, 2006). Whereas the justice literature has certainly begun to consider behavioral norms and morality more recently, behavioral ethics research has long been squarely focused on prescriptive treatments of behavior (i.e., the application of beliefs about how individuals 'should' behave; Crawshaw, Cropanzano, Bell, \& Nadisic, 2013). As such, behavioral ethics is particularly concerned with the study of moral standards and convictions (Skitka, Bauman, \& Sargis, 2005), the role of moral reasoning (Rest, Navarez, Bebeau, \& Thoma, 1999), and moral identity (Aquino \& Reed, 2002; Smith, Aquino, Koleva, \& Graham, 2014). Rest's model of morality is often applied as an organizing framework within this field, with myriad research questions centering around the four components of moral awareness, moral judgment, moral motivation, and moral action (Rest, 1986).

Many important insights have emerged from this rich literature. For example, we know that morality-related individual differences and characteristics of the immediate context interact in shaping moral awareness (Reynolds, 2006). In addition, evidence suggests that, on average, individuals reason at a less mature moral level in response to work-related (as compared to nonwork or general) issues (Weber, 1990; Weber \& Wasileski, 2001). This literature has also uncovered a number of limitations on moral cognition, including moral disengagement when individuals disengage the self-regulation that is normally guided by personal standards of ethical behavior via cognitive restructuring, minimizing one's role in the situation, or focusing on the unfavorable acts of the target (Bandura, 1999); moral licensing - when individuals take part in morally questionable behaviors after previously engaging in socially desirable behaviors (Ormiston \& Wong, 2013); and moral exclusion - when individuals consider themselves to be beyond the 
boundaries within which moral values and norms apply (Opotow, 1990). Although managers and executives may gradually become morally compromised over time, research has shown that ethical decision making can be developed through training on such biases (Banaji, Bazerman, \& Chugh, 2003; Moore, Tetlock, Tanlu, \& Bazerman, 2006). Individual differences such as moral identity (Aquino \& Reed, 2002) and locus of control (Ashkanasy, Windsor, \& Treviño, 2006) are often considered relevant to ethical decision making in organizations, as are the ethical climates that exist within organizations (Mayer, 2014; Schminke, Ambrose, \& Neubaum, 2005).

Within this special issue, Zhang, Liu, and Liu (2015) explore issues of trust and culture in negotiation settings. Specifically, they explore how different forms of trust serve to reduce the probability that deception will be used as a tactic within negotiations. They argue that both institutional and cultural differences surrounding harmony, detectability, and consequentialism lead to such crosscultural (China vs. U.S.) differences. Macklin, Martin, and Mathison (2015) then broaden our treatment of ethics (and raise it to a higher level of analysis) by proposing a model of moral climate, which integrates the literature on justice climate with that on ethical climate. Justice climate, or a work group's shared perception of how fairly they are treated, and ethical climate - a work group's shared perceptions surrounding norms of what is considered 'good' and 'bad' behavior (Li \& Cropanzano, 2009) - jointly influence moral climate. They define moral climate as group perceptions of the moral features of an organizational unit. These authors further explore how cultural diversity influences moral climates.

\section{Corporate Social Responsibility}

Corporate social responsibility (CSR) refers to firm activities focused on serving the social good that are beyond both the interest of the firm and what the law requires (Aguilera et al., 2007; Aguinis \& Glavis, 2012; Carroll, 1999; Jones \& Rupp, in press; Rupp \& Mallory, in press; Waddock, 2004; Wood, 1991, 2010). CSR is studied by a number of disciplines (law, strategy, psychology) and at a number of levels of analysis. Research at the institutional level of analysis has shown CSR to be driven by differential stakeholder expectations, pressures, and actions (e.g., Sharma \& Henriques, 2005; Stevens, Steensma, Harrison, \& Cochran, 2005), which drive action via their ability to impact firm revenue and reputation (Brammer \& Pavelin, 2006; Orlitzky, Schmidt, \& Rynes, 2003). Institutional forces such as regulations, standards, and voluntary codes of conduct can influence the amount and type of CSR practices carried out by organizations, as well as the extent to which CSR has a strategic advantage for firms (Chatterji \& Toffel, 2010). Further, the strictness of regulatory pressures may also influence the authenticity of such practices (Conley \& Williams, 2011). Consistent with both justice and behavioral ethics research, this approach is normative in nature. That is, stakeholders impose on firms strong 
expectations about how the latter should be engaging with society. It might be argued that this is an institutional application of both justice and moral norms.

At the organizational level of analysis, research has analyzed why organizations engage in CSR activities. Consistent with the literatures reviewed above, this line of research considers the instrumental, relational, and moral motives for firm-level social responsibility and environmental sustainability. For example, Bansal and Roth (2000) offer evidence of a tripartite motivational structure underlying why organizations 'go green', which includes competiveness, legitimacy, and authentic social responsibility motives (see also Davis, Schoorman, \& Donaldson's work on organizational stewardship, 1997). Considerable research has been devoted to uncovering the link between corporate social and financial performance (see Margolis, Elfenbein, \& Walsh, 2007; Orlitzky et al., 2003), although other organizational consequences of CSR activities have been uncovered, such as improved management practices (Waddock \& Graves, 1997), product quality (Agle, Mitchell, \& Sonnenfeld, 1999), and diversity (Johnson \& Greening, 1999). These various organizational-level CSR effects have been shown to depend on a number of factors related both to the organization's slack resources (e.g., Bansal, 2003) and characteristics of the firm's CSR engagement with the public (e.g., Jiang \& Bansal, 2003).

Individual-level CSR research considers the impact of CSR on individuals belonging to various stakeholder groups (e.g., employees, consumers). For example, it seems that when individuals perceive an employer (or potential employer) as socially responsible, they respond with enhanced performance, citizenship, engagement, organizational attraction, and positive job attitudes (Carmeli, Gilat, \& Waldman, 2007; Dhanesh, 2014; Glavas \& Piderit, 2009; Jones, 2010). The mediating mechanisms underlying these effects follow a similar tripartite structure as described above (instrumental, relational, and ethics-based motives), although thus far, the most common mediators to be empirically investigated have been relational in nature (e.g., trust and identity; e.g., Farooq, Payaud, Merunka, \& Valette-Florence., 2013; DeRoek, Marique, Stinglhamber, \& Swaen, 2014). Collectively, this body of work has yet to provide systematic evidence on the effect of CSR on the intended beneficiaries of CSR initiatives (beyond employees) - and the true efficacy of CSR programs in reducing human misery, creating positive social change, and influencing environmental sustainability (Margolis \& Walsh, 2003; Rupp \& Mallory, in press).

This special issue contains two papers addressing issues relevant to social responsibility. First, Cui, Liang, and Lu (2015) apply cross-cultural theory to challenge common assumptions regarding the (assumed) positive effect of CSR efforts on firm financial performance. They show empirically that this effect can actually be reversed for smaller firms in weak institutional environments. These findings open the door for continued discourse surrounding the motives for engaging in CSR and the potential barriers for smaller firms in emerging economies in actively contributing to positive social change.

Pierce and Aguinis (2015) propose a model of detrimental citizenship behavior, or actions that are carried out in order to advance organizational goals but do 
so at the expense of stakeholder interests. This study not only encourages us to think about social irresponsibility (as opposed to responsibility), it also challenges the notion of citizenship as a unidimensional and largely positive construct. Identifying the harm that may come to stakeholders in the name of organizational citizenship encourages us to view organizational behavior through the lens of multistakeholder consequentialism. Further, this study provides an important example of how CSR research (which largely focuses on organizational initiatives focused on creating social good), along with behavioral ethics studies (which focus on individuals), may provide valuable insights for understanding normative (un)ethical behavior.

\section{INTEGRATION - HOW THE THREE SHALL MERGE}

The topics of organizational justice, behavioral ethics, and CSR differ in terms of perspective and level of analysis (i.e., justice often deals with the self, behavioral ethics often deals with the context for justice and ethical decision making, and CSR involves the actions of firms). What can bring these three topics together is a focus on fairness, individual rights, and morality-based (as opposed to strictly profit-based) decisions. Research that integrates these themes requires collaborations among micro- and macro-OB, psychology, sociology, political science, law, behavioral economics, business ethics, and philosophy. This allows for topics such as morality, social norms, decision making, social influence, motivation, whistle blowing, deviance, governance, and business ethics to be studied in new ways and through new lenses (Crawshaw et al., 2013; Cropanzano \& Stein, 2009; Jones \& Rupp, in press; Trevino et al. 2006).

The interplay of the above three topics is consistent with structuration (Giddens, 1984, 1995), which focuses on the social and ethical 'practical consciousness' motivating organizations or their agents to enhance organizational legitimacy and sustainability. This perspective provides a microlevel conception of 'which institutions act where and how', acknowledging the mutual constitution of structure (e.g., governmental policies and social images) and actors (e.g., organizations managers, or employees). Such changeable structural properties of political or social systems are thought to be both the medium and the outcome of the practices that they recursively organize. At the same time, unintended conditions also arise (e.g., corruption) and act as structural constraints that organizations often cannot fundamentally change but to which they must react. Consequently, organizations must reflexively monitor their ethics and CSR actions to deal with the existing political and social systems wherein they can economically and ethically thrive. Fairness within an organization supports sustained practical consciousness such as business ethics and CSR. As such, we view organizational justice as an important organizational platform that augments the commitment to ethics and CSR performed by organizations and their members.

The movement of ethics and CSR to the forefront of global business practice signals fundamental changes in the way businesses interact with their stakeholders 
(e.g., employees, customers, local communities, and the larger society). Despite the global nature of this trend, many of these business practices have been driven by theories and research stemming from a Western context. Because responses to justice, behavioral ethics, and social responsibility cannot be meaningfully understood without reference to social, cultural, and institutional contexts, this special issue showcases current and integrative research that highlights varying cultural perspectives within the justice, ethics, and CSR domains, as well as the role of context on these issues.

\section{GONGLUSION}

Individually, each of the six papers included in this special issue makes a unique contribution. Collectively, they take an important step forward, not only in building bridges between the justice, behavioral ethics, and social responsibility literatures, but also in articulating the role of culture as an influence on the complex phenomena inherent to this domain. We hope that, through bringing together research spanning these three areas, this special issue might provide the foundation from which a number of future integrative studies sensitive to the emic-etic distinction in management research might be pursued.

\section{REFERENGES}

Agle, B. R., Mitchell, R. K., \& Sonnenfeld, J. A. 1999. Who matters to CEOs? An investigation of stakeholder attributes and salience, corporate performance, and CEO values. Academy of Management Journal, 42(5): 507-525.

Aguinis, H., \& Glavas, A. 2012. What we know and don't know about corporate social responsibility: A review and research agenda.Journal of Management, 38(4): 932-968.

Aguilera, R., Rupp, D. E. Williams, C., \& Ganapathi, V. 2007. Putting the S back in corporate social responsibility: A multi-level theory of social change in organizations. Academy of Management Revieze, 32: 836-863.

Ambrose, M. L., \& Schminke, M. 2009. The role of overall justice judgments in organizational justice research: A test of mediation. Journal of Applied Psychology, 94(2): 491-500.

Aquino, K., \& Reed, II, A. 2002. The self-importance of moral identity. Journal of Personality and Social Psychology, 83(6): 1423-1440.

Ashkanasy, N. M., Windsor, C. A., \& Treviño, L. K. 2006. Bad apples in bad barrels revisited: Cognitive moral development, just world beliefs, rewards, and ethical decision making. Business Ethics Quarterly, 16: 449-474.

Bandura, A. 1999. Moral disengagement in the perpetration of inhumanities. Personality and Social Psychology Revieze, 3: 193-209.

Banaji, M. R., Bazerman, M. H., \& Chugh, D. 2003. How unethical are you? Harvard Business Revieze, 81(12): 56-64.

Bansal, P. 2003. From issues to actions: The importance of individual concerns and organizational values in responding to natural environmental issues. Organization Science, 14: 510-527.

Bansal, P., \& Roth, K. 2000. Why companies go green: A model of ecological responsiveness. Academy of Management Journal, 43: 717-736.

Brammer, S. J., \& Pavelin, S. 2006. Corporate reputation and social performance: The importance of fit. Journal of Management Studies, 43: 435-455.

Carmeli, A., Gilat, G., Waldman, D. A. 2007. The role of perceived organizational performance in organizational identification, adjustment and job performance. Journal of Management Studies, 44(6): 972-992.

Carroll, A. B. 1999. Corporate social responsibility. Business \& Society, 38(3): 268-295. 
Chatterji, A. K., \& Toffel, M. W. 2010. How firms respond to being rated. Strategic Management Journal, 31(9): 917-945.

Colquitt, J. 2001. On the dimensionality of organizational justice: A construct validation of a measure. Journal of Applied Psychology, 86(3): 386-400.

Colquitt, J. A., Scott, B. A., Rodell, J. B., Long, D. M., Zapata, C. P., Conlon, D. E., \& Wesson, M. J. 2013. Justice at the millennium, a decade later: A meta-analytic test of social exchange and affect-based perspectives. Journal of Applied Psychology, 98(2): 199.

Conley, J. M., \& Williams, C. A. 2011. Global banks as global sustainability regulators?: The equator principles. Laze \& Policy, 33(4): 542-575.

Crawshaw, J. R., Cropanzano, R., Bell, C. M., \& Nadisic, T. 2013. Organizational justice: New insights from behavioral ethics. Human Relations, 66(7): 885-904.

Cropanzano, R., Byrne, Z. S., Bobocel, D. R., \& Rupp, D. E. 2001. Moral virtues, fairness heuristics, social entities, and other denizens of organizational justice.Journal of Vocational Behavior, 58(2): $164-209$.

Cropanzano, R., Goldman, B., \& Folger, R. 2003. Deontic justice: The role of moral principles in workplace fairness. Journal of Organizational Behavior, 24(8): 1019-1024.

Cropanzano, R., Rupp, D. E., Mohler, C. J., \& Schminke, M. 2001. Three roads to organizational justice. Research in Personnel and Human Resource Management, 20: 1-113.

Cropanzano, R., \& Stein, J. 2009. Organizational justice and behavioral ethics: Promises and Prospects. Business Ethics Quarterly, 19(2): 192-233.

Cui, Z., Liang, X., \& Lu, X. 2015. Prize or price? Corporate social responsibility commitment and sales performance in the Chinese private sector. Management and Organization Revieze, 11(1): 25-44.

Davis, J., Schoorman, F., \& Donaldson, L. 1997. Toward a stewardship theory of management. Academy of Management Journal, 22: 20-47.

De Roeck, K., Marique, G., Stinglhamber, F., \& Swaen, V. 2014. Understanding employees' responses to corporate social responsibility: Mediating roles of overall justice and organisational identification. International Journal of Human Resource Management, 25(1): 91-112.

Dhanesh, G. S. 2014. CSR as organization-employee relationship management strategy: A case study of socially responsible information technology companies in India. Management Communication Quarterly, 28: 130-49.

Farooq, O., Payaud, M., Merunka, D., \& Valette-Florence, P. 2013. The impact of corporate social responsibility on organizational commitment: Exploring multiple mediation mechanisms. Journal of Business Ethics, 125(4): 1-18.

Folger, R. 1998. Fairness as a moral virtue. In M. Schminke (Ed.), Managerial ethics: Morally managing people and processes: 13-34. Mahwah, NJ: Erlbaum.

Giddens, A. 1984. The constitution of society: outline of the theory of structuration. Berkeley, CA: University of California Press.

Giddens, A. 1995. Politics, sociology and social theory. Stanford, CA: Stanford University Press.

Gillespie, J. Z., \& Greenberg, J. 2005. Are the goals of organizational justice self-interested? In J. Greenberg \& J. A. Colquitt (Eds.), Handbook of organizational justice. Psychology Press.

Glavas, A., \& Piderit, S. K. 2009. How does doing good matter? Effects of corporate citizenship on employees. Journal of Corporate Citizenship, 36: 51-70.

Guo \& Miller 2015. Meanings and dimensions of organizational justice in China: An inductive investigation. Management and Organization Revieze, 11(1): 45-68.

Jiang, R. J., \& Bansal, P. 2003. Seeing the need for ISO 14001.Journal of Management Studies, 40(4): 1047-1067.

Johnson, R. A., \& Greening, D. W. 1999. The effects of corporate governance and institutional ownership types on corporate social performance. Academy of Management Journal, 42: $564-576$.

Jones, D. A. 2010. Does serving the community also serve the company? Using organizational identification and social exchange theories to understand employee responses to a volunteerism programme. Journal of Occupational and Organizational Psychology, 83: 857-78.

Jones, D. A., \& Rupp, D. E. in press. Social responsibility IN and OF organizations: The psychology of corporate social responsibility among organizational members. In N. Anderson, D. S. Ones, H. K. Sinangil, \& C. Viswesvaran (Eds.), Handbook of industrial, zeork, and organizational psychology (2nd ed.). Thousand Oaks, CA: Sage.

Kahneman, D., Knetsch, J. L., \& Thaler, R. H. 1986. Fairness and the assumptions of economics. Journal of Business, 59: 285-300. 
Lavelle,J., Rupp, D., Manegold,J. G., \& Thornton, M. in press. Multifoci justice and target similarity: Emerging research and extension. In M. Ambrose \& R. Cropanzano (Eds.), The Oxford Handbook of Justice in Work Organizations. Oxford: Oxford University Press.

Leung, K. 2005. How generalizable are justice effects across cultures? In J. Greenberg \& J. A. Colquitt (Eds.), Handbook of organizational justice: 555-588. Mahwah, NJ: Lawrence Erlbaum Associates.

Li, A., \& Cropanzano, R. 2009. Fairness at the group level: Justice climate and intraunit justice climate. Journal of Management, 35(3): 564-599.

Liu, X.-X., Keller, J., \& Hong, Y.-Y. 2015. Hiring of personal ties: A cultural consensus analysis of China and the United States. Management and Organization Review, 11(1): 145-169.

Macklin, R., Martin, A., \& Mathison, K. 2015. An integrated model of justice and ethical climates and the influence of cultural diversity. Management and Organizational Review, 11(1): $101-121$.

Margolis, J. D., Elfenbein, H. A., \& Walsh, J.P. 2007. Does it pay to be good? A meta-analysis and redirection of research on the relationship between corporate social and financial performance. Paper presented at the 67th Meeting of the Academy of Management, Philadelphia, PA, 2007.

Margolis, J. D., \& Walsh, J. P. 2003. Misery loves companies: Rethinking social initiatives by business. Administrative Science Quarterly, 48(2): 268-305.

Mayer, D. M. 2014. A review of the literature on ethical climate and culture. In B. Schneider \& K. Barbera (Eds.), The Oxford handbook of organizational climate and culture: 415. Oxford: Oxford University Press.

Moore, D. A., Tetlock, P. E., Tanlu, L., \& Bazerman, M. H. 2006. Conflicts of interest and the case of auditor independence: Moral seduction and strategic issue cycling. Academy of Management Review, 31: 10-49.

Opotow, S. 1990. Moral exclusion and injustice: An introduction. Journal of Social Issues, 46(1): $1-20$.

Orlitzky, M., Schmidt, F. L., \& Rynes, S. L. 2003. Corporate social and financial performance: A meta-analysis. Organization Studies, 24: 403-441.

Ormiston, M. E., \& Wong, E. M. 2013. License to ill: The effects of corporate social responsibility and CEO moral identity on corporate social irresponsibility. Personnel Psychology, 66(4), 861-893.

Pierce, J. R., \& Aguinis, H. 2015. Detrimental citizenship behavior: A multilevel framework of antecedents and consequences. Management and Organization Review, 11(1): 69-99.

Rest, J. R. 1986. Moral development: advances in research and theory. New York: Praeger.

Rest, J., Narvaez, D., Bebeau, M. J., \& Thoma, S. J. 1999. Postconventional moral thinking: A neo-Kohlbergian approach. Mahwah, NJ: Lawrence Erlbaum.

Reynolds, S. J. 2006. Moral awareness and ethical predispositions: Investigating the role of individual differences in the recognition of moral issues. Journal of Applied Psychology, 91(1): 233-243.

Rupp, D. E. 2011. An employee-centered model of organizational justice and social responsibility. Organizational Psychology Review, 1(1): 72-94.

Rupp, D. E. \& Mallory, D. in press. Corporate social responsibility: Psychological, person-centric, and progressing. Annual Review of Organizational Psychology and Organizational Behavior.

Rupp, D. E., Shao, R., Jones, K. S., \& Liao, H. 2014. The utility of a multifoci approach to the study of organizational justice: A meta-analytic investigation into the consideration of normative rules, moral accountability, bandwidth-fidelity, and social exchange. Organizational Behavior and Human Decision Processes, 123(2): 159-185.

Schminke, M., Ambrose, M. L., \& Neubaum, D. O. 2005. The effect of leader moral development on ethical climate and employee attitudes. Organizational Behavior and Human Decision Processes, 97: 135.

Shao, R., Rupp, D. E., Skarlicki, D. P., \& Jones, K. S. 2013. Employee justice across cultures: A meta-analytic review. Journal of Management, 39, 263-301.

Sharma, S., \& Henriques, I. 2005. Stakeholder influences on sustainability practices in the Canadian forest products industry. Strategic Management Journal, 26(2): 159-180.

Skitka, L. J., Bauman, C. W., \& Sargis, E. G. 2005. Moral conviction: Another contributor to attitude strength or something more? Journal of Personality and Social Psychology, 88: 895-917. 
Smith, I. H., Aquino, K., Koleva, S., \& Graham, J. 2014. The moral ties that bind ... even to outgroups: The interactive effect of moral identity and the binding moral foundations. Psychological Science, 25(8): 1554-1562.

Stevens, J. M., Steensma, H. K., Harrison, D. A., \& Cochran, P. L. 2005. Symbolic or substantive document? The influence of ethics codes on financial executives' decisions. Strategic Management Journal, 26: 181-195.

Trevino, L. K., Weaver, G. R., \& Reynolds, S. J. 2006. Behavioral ethics in organizations: A review. Journal of Management, 32(6): 951-990.

Turillo, C. J., Folger, R., Lavelle, J. J., Umphress, E., \& Gee, J. 2002. Is virtue its own reward? Selfsacrificial decisions for the sake of fairness. Organizational Behavior and Human Decision Processes, 89: 839-65.

Tyler, T. R., \& Lind, E. A. 1992. A relational model of authority in groups. In M. P. Zanna (Ed.), Advances in experimental social psychology: 115-91. San Diego, CA: Academic Press.

Waddock, S. 2004. Parallel universes: Companies, academics, and the progress of corporate citizenship. Business and Society Revieze, 109(1): 5-42.

Waddock, S. A., \& Graves, S. B. 1997. The corporate social performance. Strategic Management Journal, 8: 303-319

Weber, J. 1990. Managers' moral reasoning: Assessing their responses to three moral dilemmas. Human Relations, 43(7): 687-702.

Weber, J., \& Wasieleski, D. 2001. Investigating influences on managers' moral reasoning. The impact of context, personal, and organizational factors. Business and Society, 40(1): 79-111.

Wood, D. J. 1991. Corporate social performance revisited. Academy of Management Revieze, 16(4): 691-718.

Wood, D. J. 2010. Measuring corporate social performance: A review. International Journal of Management Reviezs, 12(1): 50-84.

Zhang, J.-D., Liu, L. A., \& Liu, W. 2015. Trust and deception in negotiation: Culturally divergent effects. Management and Organization Revieze, 11(1): 123-144.

Deborah E. Rupp (ruppd@purdue.edu; Ph.D. from Colorado State University) is Professor and William C. Byham Chair in I/O Psychology, and an affiliate faculty in the Krannert School of Management, at Purdue University. She conducts research on organizational justice, behavioral ethics, corporate social responsibility, and humanitarian work psychology, as well as issues surrounding behavioral assessment, technology, bias, and the law.

Patrick Wright (Patrick.Wright@moore.sc.edu; Ph.D. from Michigan State University) is Thomas C. Vandiver Bicentennial Chair in the Darla Moore School of Business at the University of South Carolina. He teaches, conducts research, and consults in the area of strategic human resource management (SHRM), particularly focusing on how firms use people as a source of competitive advantage and the changing nature of the chief HR officer role.

Samuel Aryee (samuel.aryee@kcl.ac.uk; Ph.D. from McMaster University) is a Professor of Organizational Behavior and Human Resource Management in the Department of Management at King's College London. His research interests include organizational justice, strategic human resource management, work-family interface, and service management.

Yadong Luo (yadong@miami.edu; Ph.D. from Temple University) is Emery Findley Distinguished Chair and Professor of Management at the University of Miami. His research interests include global business strategy, international management, and emerging economy business development. 